\title{
Yttrium Y 90-labeled Anti-FZD10 Monoclonal Antibody OTSA101
}

National Cancer Institute

\section{Source}

National Cancer Institute. Yttrium Y 90-labeled Anti-FZD10 Monoclonal Antibody

OTSA101. NCI Thesaurus. Code C99168.

A radioimmunoconjug ate composed of a humanized monoclonal antibody (MoAb) OTSA101 ag ainst FZD10 and labeled with yttrium y 90, with potential antineoplastic activity. The MoAb moiety of yttrium Y 90-labeled anti-FZD10 monoclonal antibody OTSA101 binds to FZD10, thereby delivering a cytotoxic dose of beta radiation to FZD10 positive tumor cells. FZD10 (also called CD350), a member of the Frizzled family of G protein-coupled receptors that is involved in the Wnt/beta-catenin/T CF signaling pathway, is overexpressed in a variety of cancer cell types but undetectable in normal, healthy human tissues except for the placenta. 